\title{
The distribution of chorion and amnion types in twin pregnancies
}

\author{
Rahime Nida Ergin', Murat Yayla² \\ ${ }^{1}$ Department of Obstetrics \& Gynecology, Faculty of Medicine, Bahçesehir University, Istanbul, Turkey \\ ${ }^{2}$ Department of Obstetrics \& Gynecology, International Hospital, Istanbul, Turkey
}

\begin{abstract}
Objective: Our aim was to determine the distribution of chorion and amnion sac types in twin pregnancies during the routine screening procedures during the first trimester, and to investigate their relevance with pregnancy being natural or by assisted reproductive technology.

Methods: Twin pregnancies analyzed during routine first trimester screening were evaluated retrospectively. The twins were grouped according to their conception types which are natural birth and by assisted reproductive technologies (ART). The cases which have missing or suspicious information about chorion-amnion types and with unknown conditions for pregnancies whether they were by ART or naturally were excluded from the study. In the sonographic chorionicity distinction, the presence of classic lambda and $T$ signs was considered. The unavailability of amniotic membrane among fetuses was defined as monoamniotic twin.

Results: During 14 years, 286 twin pregnancies were considered as appropriate cases to analyze. Mean maternal age was $30.47 \pm 5.07$ years, and mean week of gestation during sonography was $12.23 \pm 0.70$. Double placentas were found in $83.2 \%$ of all pregnant women, and single placenta in $16.7 \%$ of all pregnant women. While $54.5 \%(n=156)$ of twin pregnancies were ART pregnancies, $45.5 \%$ of them were natural pregnancies. It was determined that $67.7 \%$ of natural twins were diamniotic dichorionic, $27.7 \%$ of them were diamniotic monochorionic and $4.6 \%$ of them were monoamniotic monochorionic while $96.2 \%$ of ART pregnancies were diamniotic dichorionic, $3.2 \%$ of them were diamniotic monochorionic and $0.6 \%$ of them were monoamniotic monochorionic. There was statistically significant difference between ART twins and natural twins in terms of chorionicity distributions $(\mathrm{p}<0.05)$.

Conclusion: Monochorionic structure is observed more frequently in natural twins. In the follow-up of these pregnancies, early and accurate diagnosis may be the basis of early and accurate approach for the issues related with monochorionic placentation.
\end{abstract}

Keywords: Twin, assisted reproductive technologies, chorion, amnion, first trimester ultrasonography.

\section{Özet: Íkiz gebeliklerde koryon ve amniyon tiplerinin dağılımı}

Amaç: Birinci trimester rutin taramalarında ikiz gebeliklerdeki koryon ve amniyon kesesi tiplerinin dağılımının saptanması ve bunların gebeliğin doğal veya yardımcı üreme tekniği kökenli olması ile ilgisinin araştırılması amaçlandı.

Yöntem: Rutin birinci trimester taraması sırasında incelenen ikiz gebelikler retrospektif olarak değerlendirmeye alındı. İkizler doğal ve yardımcı üreme tekniği (YÜT) sonucu elde edilmiş olmalarına göre gruplandırıldı. YÜT-doğal gebelik olma durumları bilinmeyen ve koryon-amniyon bilgileri eksik veya şüpheli olgular değerlendirme dışı bırakıldı. Sonografik koryonisite ayırımında klasik lambda ve T belirtilerinin varlığı esas alındı. Amniyon zarının fetüsler arasında hiç gözlenememesi monoamniyotik ikizlik olarak tanımlandi.

Bulgular: On dört yıllık süreçte toplam 286 ikiz gebelik olgusu değerlendirilmeye uygun bulundu. Ortalama anne yaşı $30.47 \pm 5.07$ yıl, sonografinin yapıldığı ortalama gebelik haftası $12.23 \pm 0.70$ hafta idi. Tüm ikizlerin \%83.2'sinde çift, \%16.7'sinde tek plasenta varlığı saptandı. İkiz gebeliklerin \% 54.5'i (n=156) YÜT gebeliği, $\% 45.5$ 'i ise doğal gebelikti. Doğal ikizlerin \%67.7'si diamniyotik dikoryonik, \%27.7'si diamniyotik monokoryonik ve \%4.6'sı monoamniyotik monokoryonik iken, YÜT ikizlerinin \%96.2'si diamniyotik dikoryonik, \% 3.2'si diamniyotik monokoryonik ve \%0.6's1 monoamniyotik monokoryonik olarak belirlendi. YÜT ikizleri ile doğal ikizlerin koryonisite dağılımları arasında istatistiksel anlamlı farklılık bulunduğu saptandı $(\mathrm{p}<0.05)$.

Sonuç: Doğal ikizlerde monokoryonik yapıya daha fazla rastlanmaktadır. Bu gebeliklerin takiplerinde erken ve doğru tanı monokoryonik plasentasyon ile ilgili sorunlara yine erken ve doğru yaklaşılmasına temel oluşturabilir.

Anahtar sözcükler: İkiz, yardımcı üreme teknikleri, koryon, amniyon, ilk trimester ultrasonografi.
Correspondence: Dr. Rahime Nida Ergin, MD. Bahçeşehir Üniversitesi Tip Fakültesi, Kadın Hastalıkları ve Doğum Anabilim Dalı, İstanbul, Turkey. e-mail: drnidaergin@gmail.com

Received: August 12, 2014; Accepted: September 1, 2014
Bu yazının çevrimiçi İngilizce sürümü: www.perinataljournal.com/20140223011 doi: $10.2399 /$ prn.14.0223011 Karekod (Quick Response) Code: 


\section{Introduction}

It is important to present what type chorion does twin pregnancies during early pregnancy periods due to pregnancy follow-up and increase possibility of some unique fetal risks according to chorion type..$^{[1-9]}$ According to the limited number of studies in the literature, chorion structure in natural twin pregnancies is roughly tend to be $2 / 3$ dichorionic and $1 / 3$ monochorionic. ${ }^{[4,5,10-13]}$ In IVF pregnancies, generally, there is a lower rate for observing monochorionic twins. ${ }^{[4,12]}$

In this study, we aimed to find out the distribution of chorion and amnion types in twin pregnancies and to research whether this distribution changes when pregnancy is of natural type or by assisted reproductive technology (ART).

\section{Methods}

Natural and ART pregnancies that undergone first trimester ultrasonography screening between March 2000 and July 2014 were evaluated retrospectively. The cases which have missing our suspicious information about chorion-amnion types and with unknown conditions for pregnancies whether they were by ART or naturally were excluded from the study.

Chorion types were determined according to the presence or unavailability of chorionic tissue reaching up to membrane base between twins in the ultrasonography carried out between 11 and 13 weeks of gestation.
Observation of tissue presence among membranes was defined as dichorionic placentation type which was "lambda $(\lambda)$ sign or twin peak sign" and the unavailability of tissue among membrane was defined as monochorionic type placentation which was "T sign". In other words, the straight angle created by the intersection between inter-twin membrane and outer edge is defined as "T sign". Also, the image of chorion layer lying as a wedge towards inter-twin membrane is seen in the shape of lambda with a curved appearance (Fig. 1). ${ }^{[1,14]}$ Unavailability of a membrane dividing twins is a criterion for monoamniotic pregnancy.

Ultrasonographic evaluations were carried out transabdominally or transvaginally by $2 / 5 \mathrm{mHz}$ and $7 / 9 \mathrm{mHz}$ probes (Voluson 730 Expert TM; GE Healthcare, Milwaukee, WI, USA and Philips HDI 4000 ultrasound system; Philips Medical Systems, Best, Netherlands).

Statistical analyses were carried out by using free PSPP statistical software (Plaff B, Darrington J. GNU PSPP. Version 0.7.8. 2011. Free Software Foundation, Boston, MA, USA). Statistical significance level was defined as $\mathrm{p}<0.05$.

\section{Results}

Totally 286 twin pregnancy cases were evaluated. Mean maternal age was $30.47 \pm 5.07$ years. Mean week of gestation of mothers was $1.60 \pm 1.13$ and mean parity was $1.36 \pm 0.80$. Mean week of gestation for evaluating chori-
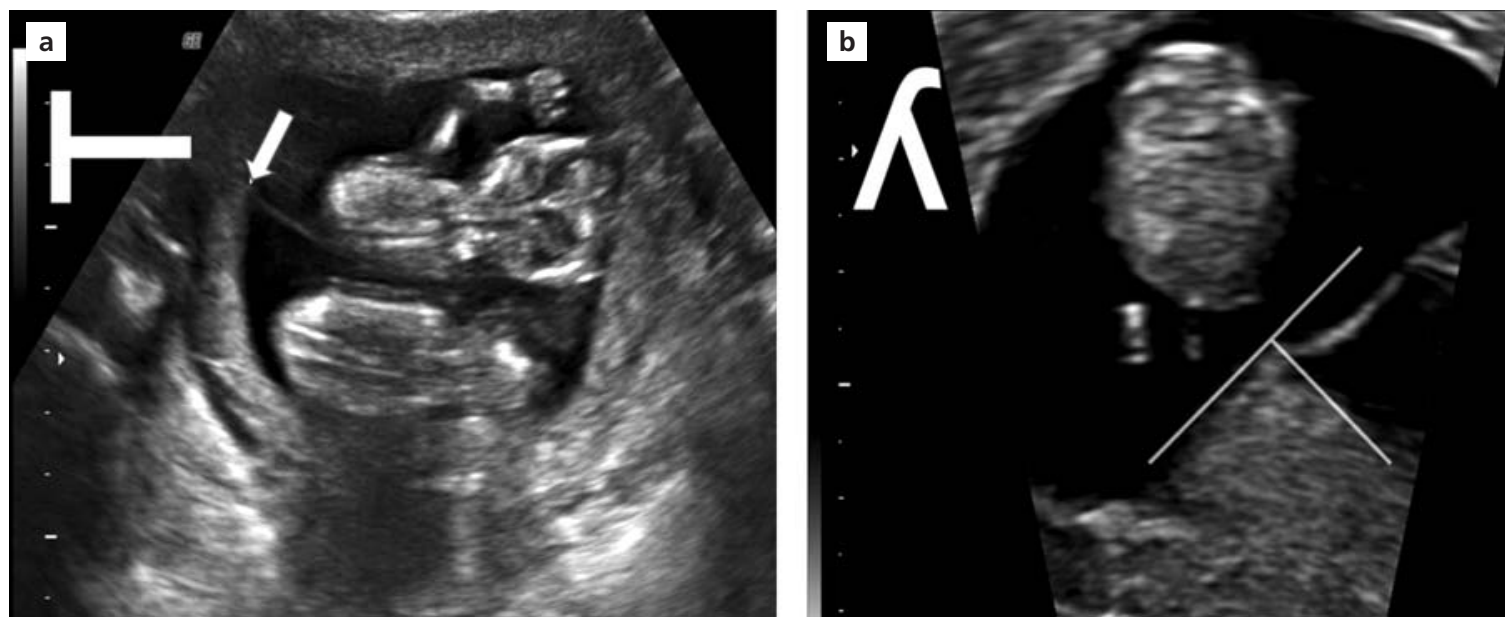

Fig. 1. (a) T sign: The straight angle created by the intersection between inter-twin membrane and outer edge (arrow). (b) Lambda sign: The reverse lambda shape of the chorion layer lying as a wedge towards inter-twin membrane. 
on type was $12.23 \pm 0.70$, and mean CRL measurement was found as $61.61 \pm 10.51 \mathrm{~mm}$. ART was applied in $54.5 \%(\mathrm{n}=156)$ of the twin pregnancies included in the study. IVF was applied to $90.4 \%(n=141)$ of ART cases and ovulation induction was applied only to $9.6 \%(n=15)$ of them. Generally, $83.2 \%$ of twins were diamniotic dichorionic, $14.3 \%$ of them were diamniotic monochorionic, and $2.4 \%$ of them were monoamniotic monochorionic. It was determined that $67.7 \%$ of natural twins were diamniotic dichorionic, $27.7 \%$ of them were diamniotic monochorionic and $4.6 \%$ of them were monoamniotic monochorionic while $96.2 \%$ of ART pregnancies were diamniotic dichorionic, $3.2 \%$ of them were diamniotic monochorionic and $0.6 \%$ of them were monoamniotic monochorionic (Fig. 2). While monochorionic placentation was 3.8\% in ART twins, it was in 32.3\% in natural twins. Monochorionic placentation was observed 9 times higher in natural pregnancies which were statistically significant. When ART and natural twins were evaluated in terms of chorionicity, statistically significant difference was observed in their distributions $(\mathrm{p}<0.05)$. When ART sub-groups were analyzed, it was seen that $95.7 \%$ of IVF cases were diamniotic dichorionic, $35.1 \%$ of them were diamniotic monochorionic, and $0.7 \%$ of them were monoamniotic monochorionic while all twin cases who undergone only ovulation induction were diamniotic dichorionic. Distribution of chorion number displayed statistically no significant difference in ART sub-groups.

\section{Discussion}

Amnion and chorion types in twin development are determined according to the timing of zygote division/separation. Two embryos with 2 different chorions, amnions and placentas (diamniotic dichorionic) appear if zygote division occurs between 1st and 3rd days of morula phase which is a division before internal cell group and any difference appear. If zygote division occurs between 4th and 8th days of blastocyst phase after the development of internal cell group, 2 embryos with 1 placenta and 1 chorion but 2 different amnions (diamniotic monochorionic) appear by the division at early blastocyst phase. If division of implanted blastocyst occurs after embryonic disk is formed between 8th and 13th days, monoamniotic monochorionic pregnancy develops since amnion is already developed. ${ }^{[15]}$ Many factors have been researched in the studies where the conditions of being dizygotic or monozygotic were analyzed rather than the mechanism for being dichorionic or monochorionic; however, no mechanism has been dis-

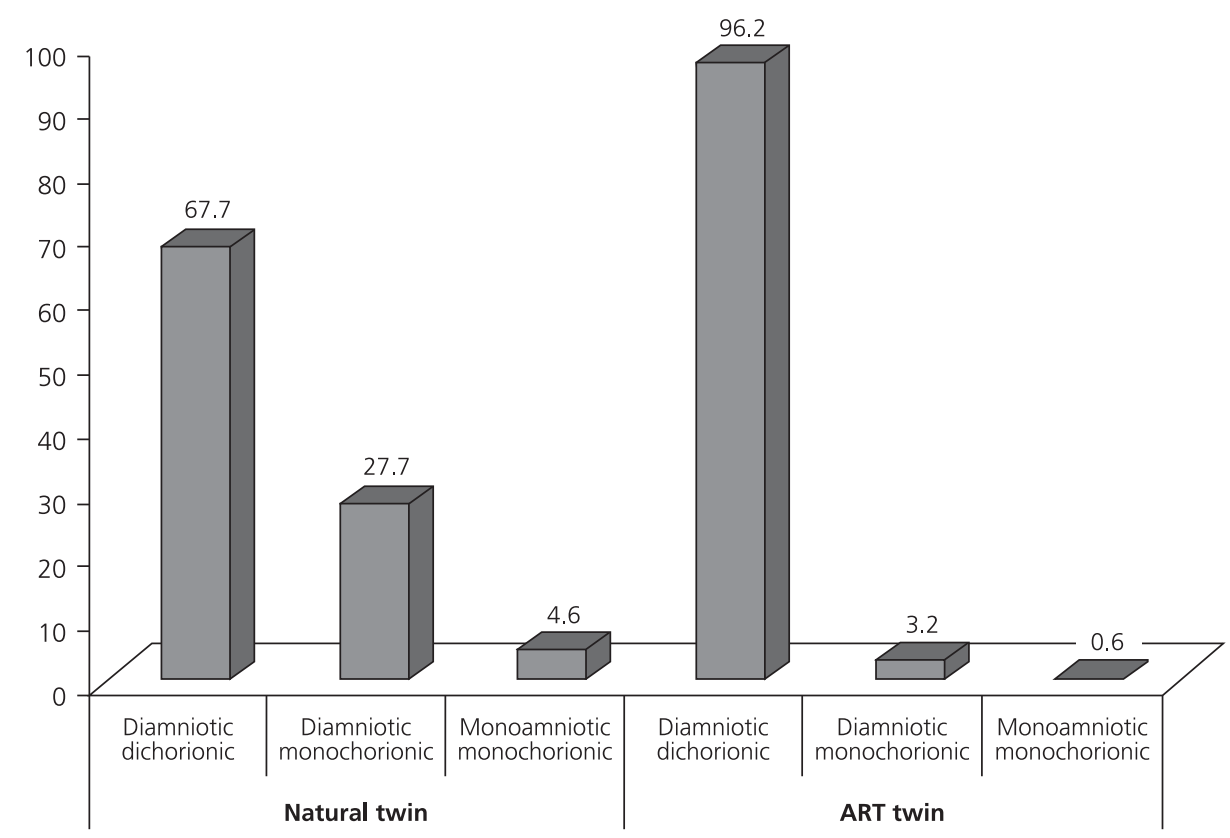

Fig. 2. Chorionicity distribution in natural and ART twins. 
covered so far. ${ }^{[16-30]}$ In family studies, the possibility of babies to be dizygotic in dizygotic mothers $(1 / 58)$ was found to be 2 times higher than in dizygotic fathers $(1 / 116) .{ }^{[16]}$ Therefore, in genetic researches carried on dizygotic twin pregnancies in which it was believed that genetic factors are mainly responsible, genetic mutations such as PPRAG (peroxisome proliferator-activated receptor gamma) at chromosome 3p25 and GDF6 which are significant in fertility and ovary function were considered as responsible. ${ }^{[17,18]}$ The possibility to be dizygotic twin increases by maternal age and parity. ${ }^{[19-21]}$ The possibility which is $1.3 \%$ during first pregnancy increases to $2.7 \%$ in 4 th pregnancy. ${ }^{[19]}$ It has been asserted that oral contraceptive and folic acid use affects dizygotic twin formation. ${ }^{[2]}$ Since our study did not question ART pregnancies in this regard, we could not differentiate the factors influencing the distribution in our series.

There have been various studies suggesting that many environmental factors may affect the monochorionic twin formation mechanics due to monozygote rather than genetics. It was shown that parity and maternal age had no effect on monozygote frequency in monochorionic twin formation. ${ }^{[23]}$ Factors such as ovary stimulation by gonadotropins, zoster manipulation, artificial incision on zona pellucida by ICSI/AH and blastomere herniation existence on such incision location, blastomere transfer, zona pellucida hardening by longterm culture, culture environment being sub-optimal and embryonic culture environment were considered to be responsible as monozygote formation mechanisms in ART cases. ${ }^{[2430]}$

In a clinical study where IVF patients undergone ovary stimulation by conventional IVF and gonadotropin were compared, it was found that monozygotic twin rate was 2 times higher in patients who had ovary stimulation. It was thought that the gonadotropin-induced changes in the structure of zona pellucida were responsible for the increase in this rate. ${ }^{[24]}$ According to the responsible mechanism, weak points are formed during the zona pellucida hardening by ovulation induction and blastocysts are herniated from these points and thus twins are formed. ${ }^{[24]}$ Also in this study, it was highlighted that embryo transfer combination on 5 th day by the changes in the structure of zona pellucida may be responsible for the increase in the rate of monozygote. ${ }^{[24]}$ With a similar mechanism, monozygotic twin may develop by artificial incision of zona pellucida by ICSI/AH and as a result of blas- tomere herniation from this incision. ${ }^{[2,26]}$ Embryo transfer timing (5-day-old embryo) was found as a risk factor independent from ICSI/AH in terms of monozygote development risk. ${ }^{[26]}$ Since there will be monozygote development in case that division occurs between 4th and 8th days, day 5 embryo transfer does not cause division but the formation of monozygote in case of division. ${ }^{[26]}$ Monozygote formation rate was also found high in blastocyst embryo transfers where no manipulation is applied..$^{[27,28]}$ According to another hypothesis, internal cell mass which is more sensitive to culture environment undergoes apoptosis and causes monozygote development by creating bipolar internal cell mass. ${ }^{[2]}$ It was also highlighted that extended time in culture environment, culture content and environment, and related laboratory experience may also have an impact on monozygote development risk. ${ }^{[30]}$ It was, however, shown that freezing procedure does not have any impact on monozygote rate. ${ }^{[31]}$

In a multi-centered epidemiological study carried out in Turkey on approximately 70,000 live births, twin delivery prevalence was found as $18.6 / 1000$ and it was found that ART was applied to $75 \%$ of them. ${ }^{[32]}$ Determining chorion type in twins during early gestational period is significant for follow-up of twin pregnancy and maternal health indirectly. Fetal complications specific to the type are observed more frequently according to the chorion type ${ }^{[1-9]}$ In a recent meta-analysis carried out according to the chorion type, it was shown that the risk of causing death of a fetus due to the death of other fetus is 5 times higher in monochorionic cases than dichorionic cases. ${ }^{[6]}$ Similarly, in studies carried out on twins in Turkey, general perinatal mortality rate was found as 107/1000 and delivery chance without any loss as $85 \%$, and no difference was observed between natural and ART pregnancies in terms of fetal neonatal mortalities. ${ }^{[7,8]}$ In another study performed in Turkey, perinatal mortality was $6 \%$ in dichorionic cases and $14 \%$ higher in monochorionic cases according to chorion type in twin pregnancies. ${ }^{[9]}$

Due to the reasons mentioned above, as recommended in the guide which is known as the RCOG (The Royal College of Obstetricians and Gynaecologists) study, it is significant to define amnion and chorion types in multiple pregnancies during early gestational periods as much as possible. ${ }^{[33]} \mathrm{We}$ aimed to minimize future confusions arising out of chorion number by carrying 
out our research during routine screening period between 11 and 14 weeks of gestation.

In a twin study, independent from being natural or IVF, $29 \%$ of the twins were reported as monochorionic and $71 \%$ of them were reported as dichorionic. ${ }^{[4]}$ In cases in another study, chorion distribution was found as $72 \%$ dichorionic and $28 \%$ monochorionic in natural twin pregnancies while it was $96 \%$ dichorionic and $4 \%$ monochorionic in IVF cases. ${ }^{[5]}$ In the studies carried out in Turkey, dichorionic twin rate was reported between $64 \%$ and $85 \%$ and monochorionic twin rate was reported between $15 \%$ and $36 \%$ independent from being natural or IVF. ${ }^{[9-11]}$

About one third of natural twins in our study were found in monochorionic type while this rate was about $4 \%$ in ART twins.

In another study which consisted of mostly twin pregnancies (72\%) and analyzed chorion type distribution in multiple pregnancies, the rate of monochorionic cases was $28.2 \%$ in natural multiple pregnancies and $5.4 \%$ in ART multiple pregnancies $(5 \%$ in ART twins). ${ }^{[12]}$ In another leading study which presented early period lambda sign in the technique for determining chorion type ultrasonographically, it was reported that $22 \%$ of twin pregnancies were generally in monochorionic type ${ }^{[13]}$ The results obtained in our study have revealed very similar rates. In our study, monochorionic type was statistically and significantly at higher rates in natural twins than ART twins.

As clearly shown in current studies, determining chorion type at an early period is very significant in terms of maternal and fetal health and follow-up. Although this study in which the chorion distribution in twins is represented according to natural and IVF pregnancies has different rates than the literature, it is confirmed that monochorionic type generally tends to be seen more in natural twin pregnancy.

\section{Conclusion}

Natural twins and ART twins are different in terms of chorion distributions. As a result, monochorionic placentation and monoamniotic amnion structure are seen more in natural twins than ART twins. Determining chorion and amnion distribution during early periods in particularly natural twins will help to plan more accurate follow-up in such twin pregnancies.

Conflicts of Interest: No conflicts declared.

\section{References}

1. Hack KE, Derks JB, Elias SG, Franx A, Roos EJ, Voerman SK, et al. Increased perinatal mortality and morbidity in monochorionic versus dichorionic twin pregnancies: clinical implications of a large Dutch cohort study. BJOG 2008;115: 58-67.

2. Barigye 1, Pasquini L, Galea P, Chambers H, Chappell L, Fisk NM. High risk of unexpected late fetal death in monochorionic twins despite intensive ultrasound surveillance: a cohort study. PLoS Med 2005;2:e172.

3. Huber A, Diehl W, Bregenzer T, Hackelöer BJ, Hecher K. Stage-related outcome in twin-twin transfusion syndrome treated by fetoscopic laser coagulation. Obstet Gynecol 2006;108:333-7.

4. Chauhan SP, Shields D, Parker D, Sanderson M, Scardo JA, Magann EF. Detecting fetal growth restriction or discordant growth in twin gestations stratified by placental chorionicity. J Reprod Med 2004;49:279-84.

5. Sperling L, Kiil C, Larsen LU, Brocks V, Wojdemann KR, Qvist I, et al. Detection of chromosomal abnormalities, congenital abnormalities and transfusion syndrome in twins. Ultrasound Obstet Gynecol 2007;29:517-26.

6. Hillman SC, Morris RK, Kilby MD. Co-twin prognosis after single fetal death: a systematic review and meta-analysis. Obstet Gynecol 2011;118:928-40.

7. Yayla M, Baytur Y. Çok merkezli çoğul gebelik çalışması 2 İkizlerde perinatal mortalite. Perinatoloji Dergisi 2009;17:8-17.

8. Yayla M, Ergin RN, Baytur Y. Çok merkezli çoğul gebelik çalışması IV - Spontan ikizlerdeki mortalitenin yardımla üreme teknikleriyle gebe kalanlardaki ikizler ile karşılaştırılması. Perinatoloji Dergisi 2011;19:1-5.

9. Yıldırım G, Gül A, Aslan H, Erol O, Güngördük K, Ceylan Y. İkiz gebeliklerde koryonisitenin neonatal ve maternal sonuçlara etkisi. J Turk Soc Obstet Gynecol 2007;4:178-83.

10. Erdemoğlu M, Kale A, Akdeniz N, Yalınkaya A, Özcan Y, Yayla M. Çoğul gebeliklerin retrospektif analizi. Perinatoloji Dergisi 2005;13:213-7.

11. Üstün Y, Engin Y, İltemir C, Cengiz B, Koç A, Cengiz L. Çoğul gebeliklerde obstetrik ve perinatal sonuçlar. MNKlinik Bilimler \& Doktor 2002;8:506-9.

12. Chow JS, Benson CB, Racowsky C, Doubilet PM, Ginsburg E. Frequency of a monochorionic pair in multiple gestations: relationship to mode of conception. J Ultrasound Med 2001; 20:757-60.

13. Sepulveda W, Sebire NJ, Hughes K, Odibo A, Nicolaides $\mathrm{KH}$. The lambda sign at 10-14 weeks of gestation as a predictor of chorionicity in twin pregnancies. Ultrasound Obstet Gynecol 1996;7:421-3.

14. Finberg HJ. The "twin peak" sign: reliable evidence of dichorionic twinning. J Ultrasound Med 1992;11:571-7.

15. Blickstein I, Keith LG. On the possible cause of monozygotic twinning: lessons from the 9-banded armadillo and from assisted reproduction. Twin Res Hum Genet 2007;10:394-9.

16. White $\mathrm{C}$, Wyshak G. Inheritance in human dizygotic twinning. N Engl J Med 1964;271:1003-5. 
17. Palmer JS, Zhao ZZ, Hoekstra C, Hayward NK, Webb PM, Whiteman DC, et al. Novel variants in growth differentiation factor 9 in mothers of dizygotic twins. J Clin Endocrinol Metab 2006;91:4713-6.

18. Busjahn A, Knoblauch H, Faulhaber HD, Aydin A, Uhlmann R, Tuomilehto J, et al. A region on chromosome 3 is linked to dizygotic twinning. Nat Genet 2000;26:398-9.

19. Pettersson F, Smedby B, Lindmark G. Outcome of twin birth. Review of 1,636 children born in twin birth. Acta Paediatr Scand 1976;65:473-9.

20. Rao TV. Maternal age, parity, and twin pregnancies. Prog Clin Biol Res 1978;24:99-103.

21. Beemsterboer SN, Homburg R, Gorter NA, Schats R, Hompes PG, Lambalk CB. The paradox of declining fertility but increasing twinning rates with advancing maternal age. Hum Reprod 2006;2:1531-2.

22. Ericson A, Källén B, Aberg A. Use of multivitamins and folic acid in early pregnancy and multiple births in Sweden. Twin Res 2001;4:63-6.

23. Bortolus R, Parazzini F, Chatenoud L, Benzi G, Bianchi MM, Marini A. The epidemiology of multiple births. Hum Reprod Update 1999;5:179-87.

24. Schachter M, Raziel A, Friedler S, Strassburger D, Bern O, Ron-El R. Monozygotic twinning after assisted reproductive techniques: a phenomenon independent of micromanipulation. Hum Reprod 2001;16:1264-9.
25. Talansky BE, Gordon JW. Cleavage characteristics of mouse embryos inseminated and cultured after zona pellucida drilling. Gamete Res 1988;21:277-87.

26. Skiadas CC, Missmer SA, Benson CB, Gee RE, Racowsky C. Risk factors associated with pregnancies containing a monochorionic pair following assisted reproductive technologies. Hum Reprod 2008;23:1366-71.

27. Sheiner E, Har-Vardi I, Potashnik G. The potential association between blastocyst transfer and monozygotic twinning. Fertil Steril 2001;75:217-8.

28. Behr B, Fisch JD, Racowsky C, Miller K, Pool TB, Milki AA. Blastocyst-ET and monozygotic twinning. J Assist Reprod Genet 2000;17:349-51.

29. Ménézo YJ, Sakkas D. Monozygotic twinning: is it related to apoptosis in the embryo? Hum Reprod 2002;17:247-8.

30. Moayeri SE, Behr B, Lathi RB, Westphal LM, Milki AA. Risk of monozygotic twinning with blastocyst transfer decreases over time: an 8-year experience. Fertil Steril 2007; 87:1028-32.

31. Blickstein I, Jones C, Keith LG. Zygotic-splitting rates after single-embryo transfers in in vitro fertilization. N Engl J Med 2003;348:2366-7.

32. Yayla M, Baytur Y. Çok merkezli çoğul gebelik çalışması 1 Epidemiyoloji. Perinatoloji Dergisi 2008;16:1-8.

33. The Royal College of Obstetricians and Gynaecologists (RCOG). Management of monochorionic twin pregnancy. Green-top Guideline No. 51; 2008. 